\title{
Adana ve Mersin illeri'nde marul yetiştirilen alanlarda Marul mozaik virüsü (Lettuce mosaic virus, LMV)'nün saptanması ve karakterizasyonu
}

\author{
Detection and characterization of Lettuce mosaic virus (LMV) in Adana and Mersin provinces in Turkey
}

\author{
Havva Nur SAĞLAM ${ }^{1}$ (D), Muharrem Arap KAMBEROĞLU ${ }^{1 \mathscr{O}}$ (D) \\ ${ }^{1}$ Çukurova University, Faculty of Agriculture, Department of Plant Protection, Adana, Turkey.
}

MAKALE BILGISI / ARTICLE INFO

Makale tarihçesi / Articlehistory:

DOI: $10.37908 / m k u t b d .822534$

Geliş tarihi /Received:06.11.2020

Kabul tarihi/Accepted:02.03.2021

\section{Keywords:}

Lettuce, LMV, DAS-ELISA, RT-PCR, sequence analysis.

Corresponding author: Muharrem Arap KAMBEROĞLU

$\bowtie$ : makamber@cu.edu.tr
ÖZET / A B S T R A C T

\begin{abstract}
Aims: This study was conducted for the detection and characterization of Lettuce mosaic virus (LMV) in the fields where the lettuce cultivation was made extensively in Adana (Ceyhan, Çukurova, Karaisalı, Sarıçam, Seyhan, Yakapınar, Yumurtalık and Yüreğir districts) and Mersin (Tarsus and Yenice districts) provinces in the autumn and winter months between 2015-2019.

Methods and Results: A total of 180 lettuce plants suspected to be infected with LMV were sampled symptomologically and tested by Double Antibody Sandwich ELISA method firstly. The presence of LMV were detected in 26 samples. In the RT-PCR studies using LMV-specific 1196; 1087 primer pair, 24 samples were found to be infected with LMV and the band a size of $800 \mathrm{bp}$ was observed in the LMV positive samples. As a result of sequence analysis was made with $5 \mathrm{LMV}$ isolates selected among them, Adana and Mersin isolates showed nucleotide similarity rate between $91.48-98.69 \%$ with LMV isolates reported from different parts of the world.

Conclusions: In this study, the survey of LMV was made in lettuce growing areas in Adana and Mersin provinces and its presence in suspicious samples was revealed.

Significance and Impact of the Study: With this study, the presence of LMV, which is one of the important viruses that cause disease in lettuce, which is amongthe top vegetables grown in many countries, was revealed by serological and molecular methods and molecular characterization was successfully made.
\end{abstract}

Atıf / Citation: Sağlam HN, Kamberoğlu MA (2021) Adana ve Mersin illeri'nde marul yetiştirilen alanlarda Marul Mozaik Virüsü (Lettuce mosaic virus, LMV)'nün saptanması ve karakterizasyonu. MKU. Tar. Bil. Derg. 26(2) : 257265. DOI: 10.37908/mkutbd.822534

\section{GiRiş}

Insan sağlığı ve beslenmesinde önemli bir yere sahip olan sebzeler, kendilerine özgü tat ve aromaları ile beğenilerek tüketilmekte ve güzel görünümleriyle sofralarımızı süslemektedir (Abak ve ark., 2010). Çok sayıda sebze türünün üretimi bakımından dünya sıralamasında ilk sıralarda yer alan Türkiye, dünya marul üretiminde, 419066 ton ile 7. sırada bulunmaktadır
(FAO, 2015). 2016 yılı verilerine göre, Türkiye'de toplam marul üretiminin yaklaşık \%20'si Adana ve Mersin illerinden karşılanmakta ve Adana ilinde 18215 da alanda 53603 ton marul üretimi yapılırken, Mersin ilinde 22847 da alanda 56164 ton marul üretimi gerçekleşmiştir (TÜiK, 2017a; 2017b).

Marul (Lactuca sativa L.), Compositae (Asteraceae) familyasının Lactuca cinsine bağı ı tek yıllık bir serin iklim sebzesidir (Eşiyok, 2012). Genellikle taze olarak 
tüketilen ve insan beslenmesinde önemli bir vitamin ve mineral madde kaynağı olan marul, dünyada ekonomik açıdan en önemli sebzelerden bir tanesidir (Dinant ve Lot, 1992; Günay, 2005). Birçok marul tür ve çeşidi (kıvırcık, göbekli, aysberg vb.) ülkemizde yetiştirilmesine rağmen, en çok tüketilen türler arasında geniş yapraklı klasik marul, kırmızı marul ve kıvırcık marul yer almaktadır (Anonymous, 2015).

Türkiye dahil olmak üzere birçok ülkede önemli sebzeler arasında ilk sıralarda yer alan marullarda hastalık oluşturan birçok fungal, bakteriyel ve viral etmenin varlığı rapor edilmiştir (Soylu, 2011; Sertkaya, 2015; Soylu ve ark., 2017). Akdeniz havzasında yetiştirilen marullarda hastalık yaptığı bildirilen önemli virüsler Çizelge 1.'de verilmiştir (Moreno ve Fereres, 2012). Diğer hastalık etmenlerinden farklı olarak viral etmenlerin kimyasal mücadelelerinin olmaması ve vektörlerinin yıl boyunca mevcut olması nedeniyle kontrol edilmeleri çok zordur. Viral hastalıklar marul gibi yaprağı yenen bitkilerde yaprakların kalitesini doğrudan etkilemekte ve böylece bitkilerin satışını engellemektedir. Bazı durumlarda, çevresel koşullara da bağlı olarak virüslerin marul bitkilerinde $\% 100$ 'e varan ekonomik kayıplara neden olduğu bildirilmiştir (Pavan ve ark., 2008).

Çizelge 1. Akdeniz havzasında marulda hastalık yapan önemli bazı viral etmenler

Table 1. Some important viral agents causing disease in lettuce in the Mediterranean basin

\begin{tabular}{lll} 
Viral Etmenler & Familya & Cins \\
Viral Agents & Family & Genus \\
\hline Alfalfa mosaic virus, AMV & Bromoviridae & Alfamovirus \\
Beet western yellows virus, BWYV & Luteoviridae & Polerovirus \\
Broad bean wilt virus, BBWV & Comoviridae & Fabavirus \\
Mirafiori lettuce big-vein virus, MiLBVV & Ophioviridae & Ophiovirus \\
Lettuce big-vein associated virus, LBVav & Rhabdoviridae & Varicosavirus \\
Lettuce mosaic virus, LMV & Potyviridae & Potyvirus \\
Lettuce necrotic yellows virus, LNYV & Rhabdoviridae & Cytorhabdovirus \\
Tomato spotted wilt virus, TWSV & Bunyaviridae & Tospovirus \\
Turnip mosaic virus, TuMV & Potyviridae & Potyvirus
\end{tabular}

Marul mozaik virüsü (LMV), dünyada ilk defa Amerika'da rapor edilmiştir (Jagger, 1921). Potyviridae familyasına bağlı tek iplikçikli bir RNA virüsüdür. Dünya çapında bulunan, mekanik, tohum, polen ve yaprak bitleri ile non-persistent taşınan LMV, potyvirus cinsinde yer almaktadır. LMV'nin en etkili vektörleri Myzus persicae (Sulzer), Aphis gossypii Glover ve Macrosiphum euphorbiae (Thomas) olarak bildirilmiş, $A$. fabae Scopoli ve Hyperomyzus lactucae (Linnaeus, 1758) daha düşük etkinlikte virüsü taşırken; Rhopalosiphum padi (L.) ve Nasonovia ribisnigri (Moley)'nin taşımadığı saptanmıştır. Fransa'da $M$. persicae'nin LMV'nin ilk tespit edilen vektörü olduğu bildirilmiştir. Bunun dışında M. euphorbiae'nin daha fazla gözlendiği, Aphis gossypii'nin ise güney bölgelerde önemli bir vektör olduğu bildirilmiştir.

LMV marulda küçülme, düzgün baş oluşturamama ve bazen nekrotik lekeler içeren oldukça çeşitli simptomlara sebep olmaktadır. LMV'ye duyarlı marul çeşitlerinde ani epidemiler gelişebilmekte ve \%80100 lere varan oranlarda kayıplar meydana gelebilmektedir (Messiaen ve Lafon, 1965; Jagger, 1921; Tomlinson, 1970; Dinant ve Lot, 1992; Nebreda ve ark.,
2004; Candresse ve ark., 2007). LMV'nin AF199 izolatının sistemik solmayı takiben lokal lezyonlara sebep olduğu, buna ilaveten Ithaca ve Vanguard 75 marul çeşitlerinde bitki ölümlerinin gözlendiği bildirilmiştir (Krause-Sakate ve ark., 2005).

LMV'nin muhtemelen marul tohumlarının uzun zamandır uluslararası ticareti aracılığı ile dünya çapında yayıldığı bildirilmiş olup, Avrupa, Kuzey ve Güney Amerika (Meksika, ABD, Arjantin, Brezilya, Uruguay), Batı Hint Adaları (Bermuda), Afrika, Orta Doğu (Mısır, İsrail, Ürdün, Irak, İran, Türkiye), Asya (Çin, Japonya) ve Okyanusya (Avustralya, Tazmanya, Yeni Zelanda) dahil olmak üzere tüm kıtalarda bulunduğu rapor edilmiştir (Dinant ve Lot, 1992).

Ülkemizde marul mozaik virüsü ilk olarak 1981 yılında Akdeniz Bölgesi marul alanlarında saptanmıştır (Yılmaz, 1981). Yapılan diğer çalışmalarla İzmir, Güney Marmara Bölgesi (Çanakkale, Balıkesir ve Bursa illeri ile ilçeleri)'nde, Ankara, Hatay, Yalova, Adana, Maraş ve Osmaniye illerinde marul mozaik virüs enfeksiyonları rapor edilmiştir (Fidan ve Türkoğlu, 1988; Sertkaya ve ark., 2009; Uzunoğulları ve Beşirli, 2011; Alan, 2012; Erkan ve ark, 2013; Sertkaya, 2015; Karanfil ve Korkmaz, 
2016; Zelyüt ve Ertunç, 2016). Ancak, etmenin moleküler olarak tanısı ve karakterizasyonu konularında yapılmış fazla bir çalışma mevcut değildir.

$\mathrm{Bu}$ çalışma, yaprak bitleri ve özellikle de tohumla taşınmasından dolayı ayrı bir öneme sahip olan LMV'nin Adana ve Mersin ili marul üretim alanlarında serolojik ve moleküler yöntemlerle saptanması, tanılanması ve elde edilen bazı LMV izolatlarının moleküler karakterizasyonlarının yapılması amacıyla yürütülmüştür. Bu amaçlar doğrultusunda, LMV ile enfekteli olduğundan şüphelenilen marul bitkilerinden alınan örnekler serolojik (DAS-ELISA) ve moleküler (PCR) yöntemler ile testlenmiş ve elde edilen bazı LMV izolatları moleküler olarak karakterize edilmiştir.

\section{MATERYAL ve YÖNTEM}

\section{Arazi çalışmaları ve bitki örneklerinin toplanması}

Bitki örneklerinin toplanması amacıyla yapılan arazi çalışmaları 2015-2019 yılları arasında sonbahar ve kış aylarında Adana ilinde Ceyhan, Çukurova, Karaisalı, Merkez, Sarıçam, Seyhan, Yakapınar, Yumurtalık ve Yüreğir ilçeleri ile Mersin ilinde Tarsus ilçesi ve Yenice mahallesinde marul yetiştiriciliğinin yoğun olarak yapıldığı alanlarda yürütülmüştür. Simptomatolojik gözlemler sonucu LMV ile enfekteli olduğundan şüphelenilen marul bitkilerinden yaprak örnekleri alınarak serolojik ve moleküler çalışmalarda materyal olarak kullanılmıştır.

Marul bitkilerinde yapraklarda mozaik, nekroz, damar açılması, küçülme, sarı lekeler ve damar nekrozu, bitkide düzgün baş oluşturmama gibi simptomlar aranmış ve bu simptomlardan en az birini gösteren bitkilerden örneklemeler yapılmıştır (Brunt ve ark., 1996; Pavan ve ark., 2008).

Alınan örnekler, numaralandırılarak buzdolabı poşetlerine konulmuş ve laboratuvara getirilerek çalışmalarda kullanılıncaya kadar kısa bir süre için $+4 C^{\circ}$ de, uzun süreler için ise $-20 C^{\circ \prime}$ de muhafaza edilmiştir.

\section{Serolojik çalışmalar}

Arazi çalışmalarında toplanan marullardan alınan bitki dokuları ilk olarak DAS-ELISA testine tabi tutulmuştur. ELISA testlerinde, ticari olarak temin edilen LMV'yespesifik ELISA kiti (Bioreba) kullanılmıştır.

ELISA testlerinde firmanın önerdiği yöntem dikkate alınmış ve modifiye edilerek uygulanmıştır. Buna göre, LMV'yespesifik $\gamma$-globulin kaplı ELISA plakasının kuyularına tampon çözeltisinde ezilerek hazırlanmış her örnekten $100^{\prime}$ er $\mu \mathrm{L}$, her bir ELISA plakasına pozitif, negatif ve tampon çözelti olmak üzere üç kontrol konularak $+4^{\circ} \mathrm{C}^{\prime}$ de gece boyu inkübasyona bırakılmıştır. Yıkama aşamasından sonra kuyulara konjugat ilave edilmiş ve plakalar $35^{\circ} \mathrm{C}^{\prime}$ de 4 saat inkübe edilmiştir. Son aşama olarak $1 \mathrm{mgmL}^{-1}$ konsantrasyonda hazırlanan substrat çözeltisinden ilave edilmiş ve 60 dakika sonra spektrofotometrik okuma yapılmıştır. Sonuçlar Thermo Scientific Multiscan Go marka ELISA okuyucusunda 405 $\mathrm{nm}$ dalga boyunda okunmuştur. Analiz sonucunda negatif kontrolde ölçülen değerin en az iki katı absorbans değeri ölçülen örnekler pozitif olarak kabul edilmiştir (Wang ve Gonsalves, 1990). Her örnek için ikişer kuyu kullanılmış ve kuyuların absorbans değerlerinin ortalamaları alınarak sonuçlar değerlendirilmiştir.

\section{Total Nükleik Asit (TNA) ekstraksiyonu}

TNA ekstraksiyon çalışmalarında, arazi çıkışlarında toplanan marul bitkilerinden alınan bitki dokuları materyal olarak kullanılmıştır. Çalışmalar, Astruc ve ark. (1996)`nın bildirdiği ekstraksiyon yöntemine göre yürütülmüştür.

\section{$R T$-PCR çalışmaları}

LMV'nin moleküler tanısı amacıyla yürütülen RT-PCR çalışmalarında, marul bitkilerinden elde edilen DNA'lar, LMV kılıf protein (CP) geninin tamamına yakın kısmını (800 bp) amplifiye eden 1196 (5'-AAG GCA GTA AAA CTG ATG-3') ve 1087 (5'-TTT ATA CTA CAG TCT TTA-3') primer çifti kullanılmıştır (Krause-Sakate ve ark., 2001). Prieto ve ark (2001)'e göre iki aşamalı olarak gerçekleştirilen RT-PCR çalışmalarında, işlemin birinci aşamasında cDNA elde etmek amacıyla, PCR tüplerinin her birine $2 \mu \mathrm{LTNA}^{\prime}$ dan, $2 \mu \mathrm{L}$ primer $\left(10 \mathrm{pmol} \mathrm{L}^{-1}\right)$ ilave edilmiş ve $95^{\circ} \mathrm{C}^{\prime} \mathrm{de} \quad 3 \mathrm{dkdenatürasyon}$ işlemi uygulandıktan sonra tüpler buz üzerine alınarak $5 \mathrm{dk}$ bekletilmiştir. Daha sonra her bir PCR tüpüne 14,6 $\mu \mathrm{l}$ sterilsaf su, $1 \mu \mathrm{LdNTP}\left(10 \mathrm{pmol}^{\mathrm{L}} \mathrm{L}^{-1}\right), 0,1 \mu \mathrm{L}$ M-MLV reverse transcriptase (RT) enzimi (Thermo Scientific), 5 $\mu \mathrm{L}$ 5XRT-buffer, $0.3 \mu \mathrm{L}$ RNase inhibitörü (Thermo Scientific) ilave edilerek son hacim $25 \mu \mathrm{L}$ olarak ayarlanmış ve tüpler thermocycler'a yerleştirilerek $42^{\circ} \mathrm{C}^{\prime}$ de $60 \mathrm{dk}$ inkübe edilerek cDNA'lar elde edilmiştir. İinci aşama olan PCR işleminde ise, yeni PCR tüpüne 2 $\mu \mathrm{LCDNA}, 16,3 \mu \mathrm{L}$ saf su, $2,5 \mu \mathrm{L} 10 \mathrm{X}$ PCR tampon çözeltisi (100 mMTris- $\mathrm{HCl}$ (pH8.8), $500 \mathrm{mMKCl}$ \% 0.8 Nonidet P40), $1,5 \mu \mathrm{L} \mathrm{MgCl}_{2}(25 \mathrm{mM}), 0,5 \mu \mathrm{LdNTP}\left(10 \mathrm{pmol}^{-1} \mathrm{~L}^{-1}\right.$ ), $0,2 \mu \mathrm{LTaq}$ DNA polymerase (Thermo Scientific), her biri $10 \mathrm{pmol} \mathrm{L}^{-1}$ olan $1 \mu \mathrm{L}$ forward primer ve $1 \mu \mathrm{L}$ reverse primer ilave edilmiştir. Daha sonra $\mathrm{PCR}$ tüpleri $94^{\circ} \mathrm{C}^{\prime} \mathrm{de}$ $3 \mathrm{dk}$; $94^{\circ} \mathrm{C}^{\prime}$ de $1 \mathrm{dk}, 42^{\circ} \mathrm{C}^{\prime}$ de $2 \mathrm{dk}, 72^{\circ} \mathrm{C}^{\prime}$ de $2 \mathrm{dk}^{\prime} \mathrm{dan}$ oluşan 35 döngü; son olarak $72^{\circ} \mathrm{C}^{\prime}$ de $10 \mathrm{dk}$ şeklinde 
ayarlanan thermocycler'a yerleştirilmiş ve PCR işlemi tamamlanmıştır.

\section{Agaroz jel elektroforez çalışmaları}

Agaroz jel elektroforez yöntemi, RT-PCR çalışmaları sonucunda elde edilen PCR ürünlerini görüntülemek amacıyla \%1.5 olacak şekilde 1X TAE tampon çözeltisi kullanılarak Galitelli ve Minafra (1994)'ya göre uygulanmıştır. Jelin boyanması için $1 \mathrm{mg}^{-1} \mathrm{~L}^{-1}$ etidyum bromid kullanılmış ve bandlar UV transillümünatörde gözlenerek fotoğrafları çekilmiştir.

\section{Dizi analizleri}

Dizi analizleri ve moleküler karakterizasyon çalışmalarında, ELISA ve RT-PCR testleri sonucunda LMV ile enfekteli olduğu saptanan örneklerden toplandıkları bölgeler dikkate alınarak izolat seçimi yapılmış ve materyal olarak kullanılmıştır.

Dizileme çalışmaları ticari olarak hizmet alımı yapılarak Molgentek firması tarafından gerçekleştirilmiştir. Dizi analizleri NCBI, Nucleotide BLAST ve MEGA7 programları kullanılarak yapılmıs ve filogenetik soyağacı Clustal W ile Kimura-2 parametresi kullanılarak Neighbor-joining metodu ile oluşturularak (Bootstrap 1000 tekrarlamalı) bu çalışmada elde edilen LMV izolatlarının dünyanın çeşitli ülkelerinden bildirilmiş olan LMV izolatları ile benzerlik oranları karşılaştırılmıştır.

\section{BULGULAR ve TARTIŞMA}

LMV izolatlarının elde edilmesi, tanılanması ve karakterizasyonu amacıyla 2015-2019 sonbahar ve kış aylarında marul yetiştiriciliğinin yaygın olarak yapıldığı alanlarda yürütülen sörvey çalışmalarında, Adana ilinde 9 ilçede 26, Mersin ilinde ise 2 ilçe/mahallede 12 marul tarlası ziyaret edilmiş ve Adana ilinde, Ceyhan'dan 10, Çukurova'dan 2, Karaisalı'dan 21, Merkez ilçeden 10, Sarıçam'dan 18, Seyhan'dan 39, Yakapınar'dan 5, Yumurtalık'tan 26 ve Yüreğir'den 6 olmak üzere 137; Mersin ilinde ise, Tarsus'tan 22 ve Yenice'den 21 olmak üzere 43, toplamda 180 marul bitkisinden örnekleme yapılmıştır (Çizelge 2).

Arazi çalışmalarında LMV ile enfekteli olduğundan şüphelenilen ve örnek alınan marul bitkilerinin yapraklarında mozaik, sarı lekelenmeler, bazen nekroz, damar açılması, küçülme ve deformasyon, genel olarak bitkide düzgün baş oluşturamama ve gelişme geriliği gibi simptomlar gözlenmiştir (Şekil 1). LMV'nin neden olduğu bu simptomlardan en az bir tanesinin gözlendiği bitkilerden alınan ve simptomatolojik olarak LMV ile enfekteli olduğundan şüphelenilen marul örneklerinin
ELISA yöntemi ile testlenmesi sonucunda, 26 örneğin LMV ile enfekteli olduğu saptanmış ve toplanan örneklerde enfeksiyon oranı $\% 14.44$ olarak hesaplanmıştır (Çizelge 2).

Bu çalışmada elde edilen sonuçlar, daha önceden diğer bazı araştırıcılar tarafından bildirilen sonuçlar ile paralellik göstermiştir. Aynı araştırıcılar, LMV'nin bu çalışmada kaydedilen simptomlara benzer simptomlar meydana getirdiği ve tek başına veya diğer bazı virüsler ile değişik oranlarda karışık enfeksiyonlara neden olduğu rapor etmişlerdir. Buna gore, Pavan ve ark. (2008), marullarda enfeksiyona neden olan virüsler içerisinde en önemlisinin tohum ve yaprak bitleriyle non-persistent olarak taşınan potyvirus, Lettuc emosaic virus (LMV) olduğunu ve LMV ile enfekteli marul bitkilerinde mozaik, küçülme, düzgün baş oluşturamama ve bazen nekroz gibi oldukça çeşitli simptomlar gözlendiğini bildirmişlerdir. Fletcher ve ark. (2005) ise, marulda cüceleşme ve sararma, yaprakta beneklenme, nekroz ve iri damar simptomları gösteren bitkilerde ELISA testleri sonucunda, en yaygın virüs hastalığının marul iri damar hastalığı olduğunu, fakat LMV, LNYV, CMV, TuMV ve BWYV gibi diğer bazı virüslerin sıklıkla karışık enfeksiyon yaptığını bildirmişlerdir. Bunlara ilaveten, Soleimani ve ark. (2011), çeşitli viral etmenlerin marul bitkisinin yapraklarında mozaik, beneklenme, kıvrılma, şekil bozukluğu, damar bantlaşması ve açılması yanında genel olarak bitkide küçük ve anormal baş oluşumuna neden olduğunu ve bu gibi simptomları gösteren marul bitkilerinden yapılan testler sonucunda, $L M V, C M V$ ve TSWV etmenlerinin varlığını sırasıyla \%21, \%16 ve \%10 oranlarında, LMV+CMV, LMV+TSWV, CMV+TSWV ve $\mathrm{LMV}+\mathrm{CMV}+\mathrm{TSWV}$ karışık enfeksiyonlarının varlığını ise, sırasıyla $\% 16, \% 8, \% 8$ ve $\% 5$ oranlarında saptadıklarını rapor etmişlerdir. Ülkemizde yapılan çalışmalarda ise, Sertkaya ve ark. (2009), arazi koşullarında marul yapraklarında mozaik lekeler, damar bandlaşması, kloroz, nekroz ve şekil bozukluğu ile bitkide gelişme geriliği gibi belirtiler gözlenen bitkilerin mekanik inokulasyon ve DAS-ELISA testleri sonucunda CMV ve LMV ile enfekteli olduğunu ortaya koyarken, Erkan ve ark. (2013), İzmir ilinde baş oluşmaması, baş dağılması, küçük baş oluşumu ve aşırı kardeşlenme gibi belirtiler gözlenen marul bitkilerinden yaptıkları ELISA testleri sonucunda, 15 marul örneğinin LMV, 5 örneğin ise CMV ile enfekteli olduğunu, 5 örnekte de LMV+CMV karışık enfeksiyonu bulunduğunu bildirmişlerdir.

ELISA testleri sonucunda, LMV ile enfekteli olduğu saptanan örneklerden arazide gösterdikleri gelişme geriliği, baş gelişiminde bozulma, yapraklarda sararma, nekroz, mozaik ve kabarcıklaşma simptomlarına 
ilaveten saptandığı bölgeler de dikkate alınarak 5 tanesi seçilmiş ve Adana'nın Seyhan ilçesinden elde edilen LMV izolatları ASh2-1, ASh3-2 ve ASh6-3 olarak,
Yakapınar izolatı AYk1-2 ve Mersin'in Tarsus izolatı MTs3-3 olarak kodlanarak moleküler çalışmalarda kullanılmıştır (Şekil 1).

Çizelge 2.Örnekleme yapılan alanlar, testlenen bitki sayısı ve ELISA testleri sonucunda LMV ile enfekteli olduğu saptanan bitki sayısı

Table 2. Sampled areas, number of plants tested and number of plants infected with LMV detected by ELISA

\begin{tabular}{|c|c|c|c|c|}
\hline $\begin{array}{l}\text { ii } \\
\text { Province }\end{array}$ & $\begin{array}{l}\text { İlçe } \\
\text { District }\end{array}$ & $\begin{array}{c}\text { Tarla Sayısı } \\
\text { Number of fields }\end{array}$ & $\begin{array}{c}\text { Testlenen Bitki Sayısı } \\
\text { Number of plantstested }\end{array}$ & $\begin{array}{c}\text { Infekteli Bitki Sayısı } \\
\text { Number of plantsinfected }\end{array}$ \\
\hline \multirow[t]{9}{*}{ Adana } & Ceyhan & 1 & 10 & 0 \\
\hline & Çukurova & 1 & 2 & 0 \\
\hline & Karaisalı & 5 & 21 & 0 \\
\hline & Merkez & 2 & 10 & 0 \\
\hline & Sarıçam & 5 & 18 & 0 \\
\hline & Seyhan & 6 & 39 & 24 \\
\hline & Yakapınar & 2 & 5 & 1 \\
\hline & Yumurtalık & 3 & 26 & 0 \\
\hline & Yüreğir & 1 & 6 & 0 \\
\hline \multirow[t]{3}{*}{ Mersin } & Tarsus & 6 & 22 & 1 \\
\hline & Yenice & 6 & 21 & 0 \\
\hline & Toplam & 38 & 180 & 26 \\
\hline
\end{tabular}

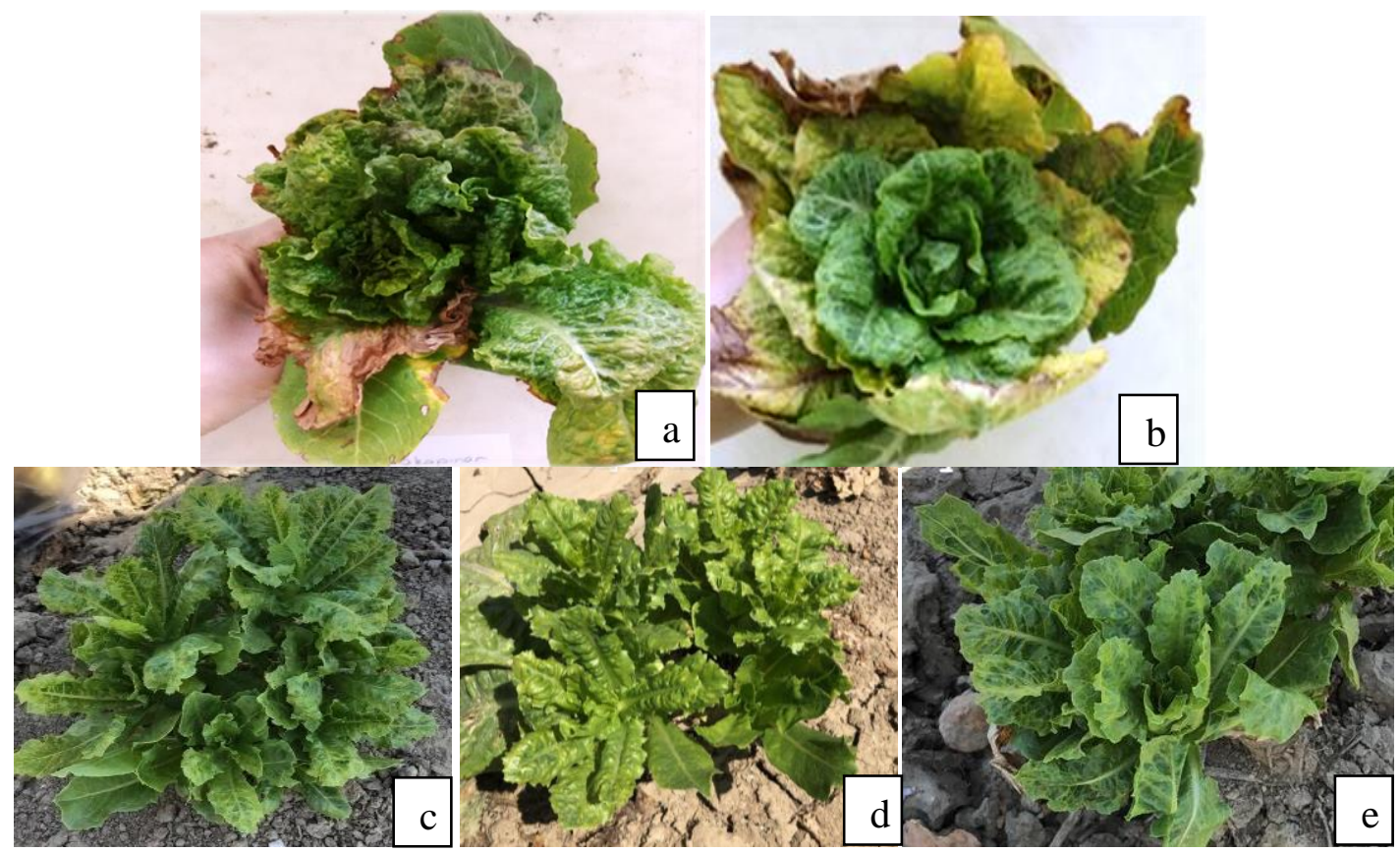

Şekil 1. LMV ile enfekteli marul bitkilerinde baş oluşturamama, gelişme geriliği, yapraklarda mozaik, sararma, nekroz ve deformasyon simptomları [a. Yakapınar izolatı (AYk1-2); b. Tarsus izolatı (MTs3-3); c, d, e. Seyhan izolatları (ASh2-1, ASh3-2 ve ASh6-3)]

Figure 1. LMV infected lettuce plants, inability to form head, growth retardation and mosaic, yellowing, necrosis and deformation symptoms in the leaves [(a. Yakapınar isolate (AYk1-2); b. Tarsus isolate (MTs3-3); $c$, d, e. Seyhan isolates ( ASh2-1, ASh3-2 and ASh6-3)]

Seçilen izolatların ve LMV ile enfekteli diğer bazı örneklerin LMV'ye spesifik 1196; 1087 primer çifti kullanılarak yapılan RT-PCR çalışmaları sonucunda, kılıf protein geninin hemen hemen tamamı olan büyüklükte 
bir bölge çoğaltılmış ve 800 bp'lik band elde edilmiştir (Şekil 2). Bu çalışmanın sonuçları, Krause-Sakate ve ark. (2001)'nın yapmış oldukları çalışmanın sonuçlarıyla paralellik göstermiştir. Benzer şekilde aynı araştırıcılar marul bitkisi üzerinde LMV'nin saptanması amacıyla 1196; 1087 primer çiftini kullanarak 800 bp büyüklüğe sahip band gözlediklerini rapor etmişlerdir.

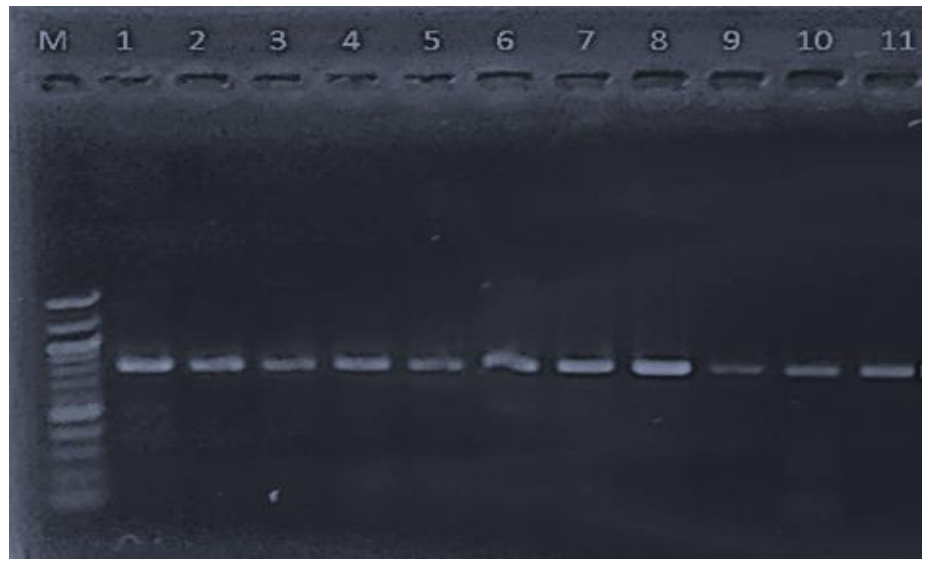

Şekil 2. RT-PCR çalışmaları sonucunda Seyhan, Yakapınar ve Tarsus izolatları ile LMV ile enfekteli olduğu saptanan diğer bazı marul örneklerinden elde edilen 800 bp büyüklüğünde bandlar [M, Marker; 1,2,3nolu örnekler Seyhan izolatları (sırasıyla ASh2-1, ASh3-2 ve ASh6-3); 4 nolu örnek Yakapınarizolatı (AYk1-2); 5 nolu örnek Tarsus izolatı

(MTs3-3); 6,7,8,9,10,11 nolu kuyular LMV ile enfekteli diğer marul örnekleri]

Figure 2. As a result of RT-PCR studies, $800 \mathrm{bp}$ bands, obtained from Seyhan, Yakapınar and Tarsus isolates with some other lettuce samples found to be infected with LMV [M, Marker; Examples 1,2,3 are Seyhan isolates (ASh2-1, ASh3-2 and ASh6-3, respectively); Example 4 Yakapınar isolate (AYk1-2); Example 5 Tarsus isolate (MTs3-3); Other lettuce samples infected with $L M V$ wells $6,7,8,9,10,11]$

LMV'nin Adana ve Mersin izolatlarının dizileme sonucu elde edilen nükleotid dizileri dünyanın diğer ülkelerinden rapor edilen LMV izolatları ile karşılaştırıldığında \%91.48-98.69 arasında benzerlik oranları göstermiştir. En yüksek benzerlik oranı (\%98.69) Fransa (X97704.2) ve Hindistan (JQ794776.1) izolatları ile elde edilirken, en düşük benzerlik oranı (\%91.48) Yemen izolatı (Z78227.1) ile saptanmıştır. Bu çalışmada elde edilen LMV izolatlarının dünyada yer alan diğer izolatlarla benzerlik oranları Çizelge 3 'de verilmiştir.

Çizelge 3. Filogenetik karşılaştırmada kullanılan LMV izolatlarının erişim numaraları, orjinleri ve bu çalışmada elde edilen LMV izolatları ile benzerlik oranları

Table 3. Accession numbers and origins of LMV isolates used in phylogenetic comparison and similarity rates with LMV isolates obtained in this study

\begin{tabular}{llll}
\hline Erişim No & Benzerlik Oranları (\%) & Orjin & Konukçu \\
Accession Number & Similarity Rates (\%) & Origin & Lettuce \\
\hline X97704.2 & $\% 98,69$ & Fransa & Lettuce \\
JQ794776.1 & $\% 98,69$ & Hindistan & Lettuce \\
KX378986.1 & $\% 98,52$ & Türkiye & Lettuce \\
KF955619.1 & $\% 98,21$ & Güney Kore & Lettuce \\
AJ278854.1 & $\% 96,77$ & Brezilya & Lettuce \\
U24670.1 & $\% 96,30$ & ABD & Lettuce \\
X97705.1 & $\% 95,70$ & Fransa & Lettuce \\
Z78229.1 & $\% 94,19$ & Yunanistan & Lettuce \\
Z78230.1 & $\% 93,94$ & Yunanistan & Cattuce \\
Z78228.1 & $\% 93,79$ & Yunanistan & Lettuce \\
KF268956.1 & $\% 91,77$ & Fransa & Yemen roseus \\
Z78227.1 & $\% 91,48$ & Caranth & L
\end{tabular}


LMV için elde edilen PCR ürünlerinin nükleotid dizilerinin analizleri sonucunda oluşturulan filogenetik ağaç üzerinde, 4 farklı grup ortaya çıkmıştır. Adana Seyhan izolatları (ASh2-1, ASh3-2, ASh6-3) ile Mersin Tarsus izolatı (MTs3-3), Türkiye'den rapor edilen KX378986.1 nolu LMV izolatı da dahil olmak üzere, Hindistan (JQ794776.1), Güney Kore (KF955619.1), Brezilya (AJ278854.1), Amerika Birleşik Devletleri (U24670.1) ve Fransa (X97704.2 ve X97705.1) izolatları ile birlikte aynı büyük grupta yer alırken, Adana Yakapınarizolatı (AYk1-2) diğer bir Fransa izolatı (KF268956.1) ile farklı bir grubu oluşturmuştur. LMV'nin Yunanistan ve Yemen izolatları ise ayrı ayrı gruplanmışlardır (Şekil 3). Benzer şekilde, Svanella-
Dumas ve ark (2014), genetik olarak birbirine yakın olan klasik LMV izolatlarına ilaveten, bu izolatlardan ayrıca kendi aralarında farklılıklar gösteren izolatların bulunduğunu ve bunların sınıflandırmada dört grup oluşturduklarını rapor etmişlerdir. Karanfil ve ark. (2018) da genel olarak LMV izolatlarının filogenetik ağaç üzerinde Yemen (Z78227.1), Fransa (KF268956.1), Yunanistan (Z78228.1, Z78229.1, Z78230.1) ve diğer izolatları içeren bir grup olmak üzere 4 gruba dallandıklarını ve Güney Marmara bölgesinde Balıkesir, Bursa ve Çanakkale illerini kapsayan survey çalışmaları sonunda toplanan LMV izolatlarının dünyanın birçok ülkesinden rapor edilen izolatları içeren büyük grubun içinde yer aldığını bildirmişlerdir.

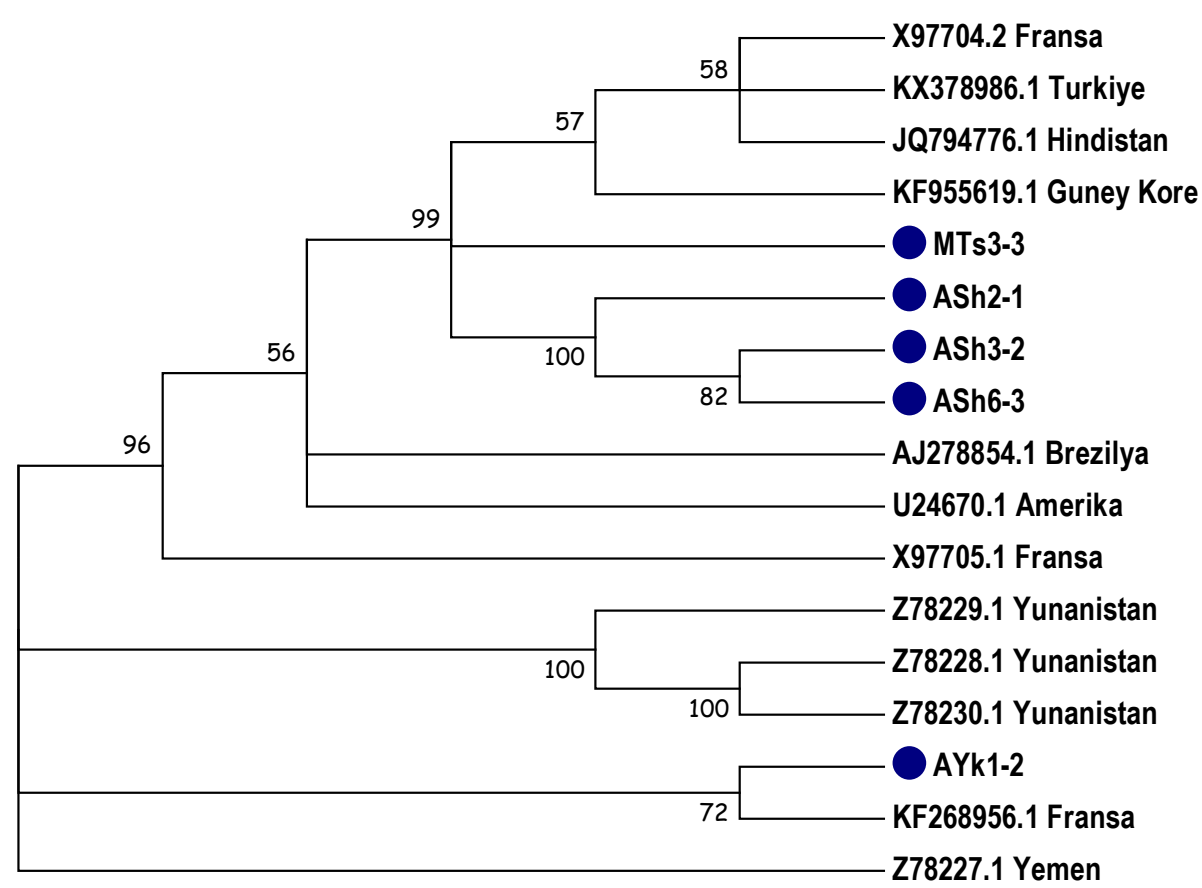

Şekil 3. LMV Seyhan izolatları (ASh2-1, ASh3-2, ASh6-3), Tarsus izolatı (MTs3-3) ve Yakapınar izolatı (AYk1-2) ile dünyadan rapor edilen LMV izolatları kullanılarak Neighbor-joining metodu ile oluşturulmuş filogenetik soyağacı (1000 tekrarlamalı)

Figure 3. Phylogenetic tree formed by Neighbor-joining method using LMV Seyhan isolates (ASh2-1, ASh3-2, ASh6-3), Tarsus isolate (MTs3-3) and Yakapınar isolate (AYk1-2) and LMV isolates reported from around the world. Bootstrap values (1000 replicates)

Sonuç olarak, yapılan bu çalışmada, Adana ve Mersin illeri marul üretim alanlarında LMV'nin varlığı ELISA ve RT-PCR yöntemleri kullanılarak saptanmış ve bunlar arasından alındıkları il ve ilçeye göre seçilen LMV izolatlarının [Adana Seyhan izolatları (ASh2-1, ASh3-2, ASh6-3), Mersin Tarsus izolatı (MTs3-3) ve Yakapınar izolatı (AYk1-2)] moleküler karakterizasyonu yapılmıştır. Bu çalışmanın yürütüldüğü Adana ve Mersin illerinde 100000 tonun üzerinde üretim miktarına sahip marul, bölge için ekonomik öneme sahip kışlık sebzelerden biridir. Bu bölgede hastalık etmenleri ve zararlılar verim ve kalitede önemli kayıplara sebep olmaktadır. Bu etmenler içerisinde virüslere karşı, yapılacak olan etkili bir vektör mücadelesine ek olarak, virüsten ari tohum ve üretim materyalinin kullanılması, yabancı ot kontrolü, koruyucu kültürel uygulamalar, dayanıklı veya tolerant çeşitlerin üretimi ve üreticiler tarafından tercih edilmesi çok önemlidir. Bundan sonra, özellikle dayanıklı veya tolerant çeşitlerin elde edilmesi ve bu çeşitlerin LMV izolatlarına tepkilerinin ortaya 
konulması, dayanıklılık kıran LMV ırklarının saptanması, LMV'ye konukçuluk yapan yabancı ot konukçularının belirlenmesi gibi LMV'nin mücadelesine yönelik konularda çalışmaların planlanması ve bunlara öncelik verilmesi, elde edilen sonuçların pratiğe aktarılması ve üreticilerin bilinçlendirilmesi gerekmektedir.

\section{ÖZET}

Amaç: Bu çalışma 2015-2019 yılları arasında sonbahar ve kış aylarında Adana (Ceyhan, Çukurova, Karaisalı, Sarıçam, Seyhan, Yumurtalık ve Yüreğir ilçeleri ile Yakapınar mahallesi) ve Mersin (Tarsus ilçesi ile Yenice mahallesi) illerinde yaygın olarak marul yetiştiriciliğinin yapıldığı alanlarda marul mozaik virüsü (Lettuce mosaic virus, LMV)'nün saptanması ve karakterizasyonu amacıyla yürütülmüştür.

Yöntem ve Bulgular: Arazi çıkışlarında simptomatolojik olarak LMV ile enfekteli olduğundan şüphelenilen toplam 180 adet marul bitkisinden örnekleme yapılmış ve toplanan örnekler öncelikle Double Antibody Sandwich ELISA (DAS-ELISA) yöntemi ile testlenmiştir. Toplam 26 örnekte LMV'nin varlığı saptanmıştır. LMV'ye spesifik primer çifti $(1196 ; 1087)$ kullanılarak yapılan RTPCR çalışmalarında ise, 24 örnek LMV ile enfekteli bulunmuş ve 800 bp büyüklüğünde band elde edilmiştir. Bunlar arasından seçilen 5 LMV izolatı ile yapılan sekans analizleri sonucunda, Adana ve Mersin izolatları dünyanın diğer ülkelerinden rapor edilen LMV izolatları ile \%91.48-98.69 arasında benzerlik göstermiştir.

Genel Yorum: Bu çalışmada Adana ve Mersin illerinde marul yetiştirilen alanlarda LMV'ninsurveyi yapılmış ve araştırılan örneklerde varlı̆̆ı ortaya konulmuştur.

Çalışmanın Önemi ve Etkisi: Bu çalışma ile birçok ülkede yetiştirilen sebzeler arasında ilk sıralarda yer alan marullarda hastalık oluşturan önemli virüslerden biri olan LMV'nin varlığı serolojik ve moleküler yöntemlerle ortaya konulmuş ve moleküler olarak karakterizasyonu başarıyla yapılmıştır.

Anahtar Kelimeler: Marul, LMV, DAS-ELISA, RT-PCR, dizi analizi.

\section{TEŞEKKÜR}

Bu çalışma, Çukurova Üniversitesi BAP birimi tarafından desteklenmiş olan FYL-2016-7227 proje numaralı yüksek lisans tezinin bir kısmını kapsamaktadır

\section{ÇIKAR ÇATIŞMA BEYANI}

Makale yazarları aralarında herhangi bir çıkar çatışması olmadığını beyan ederler.

\section{ARAŞTIRMACILARIN KATKI ORANI BEYANI}

Yazarlar makaleye eşit oranda katkı sağlamış olduklarını beyan ederler.

\section{KAYNAKLAR}

Abak A, Düzyaman E, Şeniz V, Gülen $H$, Pekşen A, Kaymak HÇ (2010) Sebze üretimini geliştirme yöntem ve hedefleri. Ziraat Mühendisliği VII. Teknik Kongresi,Ocak 11-15, Ankara, 477-492.

Alan B (2012) Doğu Akdeniz Bölgesi'nde yetiştirilen bazı kışlık sebzelerde hastalık yapan virüslerin tanılanması ve karakterizasyonu. Doktora Tezi, Çukurova Üniveritesi, Fen Bil. Ens., Bitki Koruma ABD, 134s.

Anonymous (2015) Kış sebzeleri nelerdir. https://evhayat.com/kis-sebzeleri-nelerdir/

(ErişimTarihi: 20 Ekim 2015).

Astruc N, Marcos JF, Macquarie G, Candresse GT, Vicent $P$ (1996) Studies on the diagnosis of Hop stunt viroid in fruit trees: Identification of new host and application of a nucleic acid extraction procedure based on non-organic solvents. Eur. J. Plant Pathol. 102: 837-846.

Brunt AA, Crabtree K, Dallwitz MJ, Gibbs AJ, Watson L (1996) Viruses of plants. Descriptions and lists from the WIDE Database. CAB International, Wallingford. 1484.

Candresse T, Lot H, German-Retana S, Krause-Sakate R, Thomas J, Souche S, Delaunay T, Lanneau M, Le Gall O (2007) Analysis of the serological variability of Lettuce mosaic virus using monoclonal antibodies and surface plasmon resonance technology. J. Gen. Virol. 88: 2605-2610.

Dinant S, Lot H (1992) Lettuce mosaic virus. Plant Pathol. 41: 528-542.

Erkan S, Gümüş M, Paylan iC, Duman I, Ergün M (2013) İzmir ili ve çevresindeki bazı kışlık sebzelerde görülen viral etmenlerin saptanması. Ege Üni .Zir. Fak. Derg. 50(3): 311-322.

Eşiyok D (2012) Kışlık ve Yazlık Sebze Yetiştiriciliği. Meta Basım, Bornova/İzmir. 410s.

FAO (2015) The world lettuce economy. http://www.fao.org/faostat/en/\#data (ErişimTarihi: 19 Ekim 2015).

Fidan Ü, Türkoğlu T (1988) Ege Bölgesi marul bitkilerinde görülen virüs hastalıkları üzerinde ön çalışmalar. Bitki Koruma Bülteni 28(1-2): 43-56.

Fletcher JD, France CM, Butler RC (2005) Virus surveys of lettuce crops and management of Lettuce BigVein Disease in New Zealand. New Zealand Plant Protection 58: 239-244. 
Galitelli D, Minafra A (1994) Electroforesis. Course on Plant Virus Diagnosis, October 15-30. Adana-Turkey. Page: 89-99.

Günay A (2005) Sebze Yetiştiriciliği, Cilt II. İzmir, 531s.

Jagger IC (1921) A transmissible mosaic disease of lettuce. J. Agric. Res. 20: 737-741.

Karanfil A, Korkmaz S (2016) Güney Marmara Bölgesi marul üretim alanlarında Marul mozaik virüsü (Lettuce mosaic virus; LMV) izolatlarının kılıf protein genine gore moleküler karakterizasyonu. Uluslararası Katılımlı Türkiye VI. Bitki Koruma Kongresi. Eylül 5-8, Konya, $938 \mathrm{~s}$.

Karanfil A, Çevik B, Korkmaz S (2018) Detection of Lettuce mosaic virus infection in South Marmara Region of Turkey and coat protein gene characterization. Zemdirbyste 105(4): 363-368.

Krause-Sakate R, Mello RN, Pavan MA, Zambolim EM, Carvalho MG, Le Gall O, Zerbini FM (2001) Molecular characterization of two Brazilian isolates of Lettuce Mosaic Virus with distinct biological proporties. Fitopotologia Brasileira 26: 153-157.

Krause-Sakate $R$, Redondo $E$, Richard-Forget $F$, Jadao AS, Houvenaghel MC, German-Retana S, Pavan MA, Candresse T, Zerbini FM, Gall OL (2005) Molecular mapping of the viral determinants of systemic wilting induced by a Lettuce Mosaic Virus (LMV) isolate in some lettuce cultivars. Vir. Res. 109: 175180.

MessiaenMC, Lafon R (1965) Les Maladies Des Plantesmaraicheres, Vol; II, IRA.pp 272-276.

Moreno A, Fereres A (2012) Virus diseases in lettuce in the Mediterrenean Basin. Adv. Virus Res. 84: 247248.

Nebreda M, Moreno A, Perez N, Palacios I, SecoFernandez V, Fereres A (2004) Activity of Aphids associated with lettuce and broccoli in Spain and their efficiency as vectors of Lettuce Mosaic Virus. Virus Res. 100: 83-88.

Pavan MA, Krause-Sakate R, Silva N, Zerbini FM, Gall OL (2008) Virus diseases of lettuce in Brazil. Plant Viruses. M. Pavan (corresponding author), Plant Viruses, Global Science Books, Viçosa. pp 35-40.

Prieto H, Bruna A, Hinrichsen P, Munoz C (2001) Isolation and molecular characterization of a Chilean isolate of Zucchini yellow mosaic virus. Plant Dis. 85: 644-648.

Sertkaya G, Karaca F, Nurel S, Yokarıbaş H (2009) Marul alanlarında Marul mozaik virüsü ve Hıyar mozaik virüsü'nün biyolojik ve serolojik yöntemlerle araştırılması. Türkiye III. Bitki Koruma Kongresi, Temmuz 15-18, Ankara, 380s.
Sertkaya G (2015) Hatay ili marul ve ıspanak alanlarında bazı virüslerin araştırılması. Mustafa Kemal Üni. Zir. Fak. Derg. 20(1): 7-12.

Soleimani P, Mosahebi G, Koohi-Habibi M (2011) Identification of some viruses causing mosaic on lettuce and characterization of Lettuce mosaic virus from Tehran province in Iran. Afr. J. Agric. Res. 6(13): 3029-3035.

Soylu S (2011) Marul (Lactuca sativa L.) bitkisinde beyaz çürüklük hastalığına (Sclerotinia sclerotiorum (Lib.) de Bary) karşı kök bakterilerinin kullanım olanakları. Alatarım 10: 85-93

Soylu S, Sertkaya E, Üremiş I, Bozkurt IA, Kurt Ş (2017) Hatay ili marul (Lactuca sativa L.) ekim alanlarında görülen önemli hastalık etmenleri, zararlı ve yabancı ot türleri ve yaygınlık durumları. Mustafa Kemal Üni. Zir.Fak.Derg. 22: 23-33.

Svanella-Dumas L, Verdin E, Faure C, German-Retana S, Gognalons P, Danet JL, Marais A, Candresse T (2014) Adaptation of Lettuce mosaic virus to Catharanthus roseus involves mutations in the central domain of the VPg. Mol. Plant Microbe. Interact. 27(5): 491497.

Tomlinson JA (1970) Lettuce mosaic virus. Desciptions of plant viruses. No. 9. Common Wealth. Mycological Institute of Associated and Applied Biology, Kew, England.

TÜiK (2017a) Adana ilinde Marul Üretimi, 2012-2016. https://biruni.tuik.gov.tr/bitkiselapp/bitkisel.zul (ErişimTarihi: 14 Eylül 2017).

TÜiK (2017b) Mersin ilindemarulüretimi, 2012-2016. https://biruni.tuik.gov.tr/bitkiselapp/bitkisel.zul (ErişimTarihi: 14 Eylül 2017).

Uzunoğulları N, Beşirli G (2011) Yedikule marul (L.S.L. var. Longifolia) çeşidinde zarar yapan bazı viral etmenlerin tanılanması. Türkiye 4. Bitki Koruma Kongresi. Haziran28-30, Kahramanmaraş, 496s.

Wang M, Gonsalves D (1990) ELISA detection of various tomato spotted wilt virus isolates using specific antisera to structural proteins of the virus. Plant Dis. 75: 154-158.

Yılmaz MA (1981) Virus particles associated with disease of tomato and lettuce in Turkey. Phytopath. Medit. 2: 79-80.

Zelyüt RF, Ertunç $F$ (2016) Ankara ili marul ekim alanlarında saptanan virus enfeksiyonları. Uluslararası Katılımlı Türkiye VI. Bitki Koruma Kongresi, Eylül 5-8, Konya, 938s. 